Gut, 1977, 18, 817-820

\title{
Gastric epithelial cell turnover, mucus production, and healing of gastric ulcers with carbenoxolone ${ }^{1}$
}

\author{
W. DOMSCHKE, S. DOMSCHKE, J. HAGEL, L. DEMLING, AND \\ D. N. CROFT ${ }^{2}$
}

From the Department of Medicine, University of Erlangen-Nürnberg, Erlangen, West Germany, and St. Thomas' Hospital, London

SUMMARY Nineteen healthy subjects were studied and 17 patients with gastric ulcer before and after ulcer healing with carbenoxolone. Gastric deoxyribonucleic acid (DNA) loss was measured as an index of epithelial cell turnover, and N-acetylneuraminic acid (NANA) content of gastric juice as an index of mucus secretion. In normal subjects there was a negative correlation $(P<0.025)$ between gastric DNA loss and NANA secretion; the lower the cell turnover the higher the NANA production. In gastric ulcer patients DNA loss or turnover was significantly $(P<0.01)$ higher than normal, and fell significantly $(P<0.01)$ after four weeks' treatment with carbenoxolone when 16 of the 17 ulcers had healed. At the same time NANA output increased significantly $(P<0.01)$. It is suggested that patients with gastric ulcer lose cells at a high rate, a state of affairs which is returned towards normal by carbenoxolone, thus allowing the epithelial cells to mature within the mucosa and produce more mucus.

In gastric ulcer patients, carbenoxolone sodium influences several of the features of proliferating and differentiating gastric epithelial cells. Proliferation is reduced (Lipkin, 1970; Croft, 1973) and differentiation-estimated in terms of mucus production-is enhanced (Goodier et al., 1967; Gheorghiu et al., 1971; Domschke et al., 1972). The present study was designed to investigate the effects of carbenoxolone treatment on both of these processes in gastric ulcer patients. As a measure of cell turnover deoxyribonucleic acid (DNA) was determined in gastric washings (Croft et al., 1966), and as an index of cell maturation, mucus secretion of $\mathrm{N}$-acetylneuraminic acid (NANA) (Domschke et al., 1972) was measured in the gastric juice.

\section{Methods}

SUBJECTS AND INVESTIGATIVE DESIGN Nineteen healthy subjects (12 males, seven females, mean age 42 years, range 25 to 62 years, and mean

${ }^{1}$ The data in this paper were presented at the World Congress of Gastroenterology in Budapest in June 1976 and at the Symposium on Mucus in Health and Disease at the University of Surrey, Guildford, in September 1976.

${ }^{2}$ Author to whom reprint requests should be sent.

Received for publication 28 February 1977 weight $69 \mathrm{~kg}$, range 48 to $89 \mathrm{~kg}$ ), and 17 patients (14 males, three females, mean age 52 years, range 34 to 69 years, mean weight $66 \mathrm{~kg}$, range 51 to $86 \mathrm{~kg}$ ) in whom a benign gastric ulcer was diagnosed radiologically and endoscopically were studied. In none of the patients was an ulcer or ulcer scar of the duodenum detectable. Each subject and patient gave informed consent to their participation in the study. Gastric samples for DNA loss rate were obtained by the gastric perfusion technique (Croft and Lubran, 1965; Croft et al., 1966), and samples for basal gastric secretion of glycoprotein $\mathrm{N}$-acetylneuraminic acid (NANA) were obtained on a separate occasion employing conventional gastric aspiration. In gastric ulcer patients, both tests were repeated after four weeks of treatment with carbenoxolone sodium (dosage schedule: $300 \mathrm{mg}$ per day for the first week, followed by $150 \mathrm{mg}$ per day thereafter).

MEASUREMENT OF GASTRIC DNA LOSS

Gastric perfusion tests were performed essentially as described in detail by Croft et al. (1966). Briefly, after an initial washout of fasting gastric contents (first specimen), three $500 \mathrm{ml}$ portions of $0.9 \%$ saline were perfused consecutively through the stomach and aspirated over a timed period to yield the second, third, and fourth specimens. The DNA in the whole 
of each gastric washing was precipitated, extracted, and estimated in duplicate by the Burton method (Burton, 1956) as modified by Croft and Lubran (1965) to prevent interference from sialic acid present in mucus. The DNA values were related to the amount of phosphorus in the standard solution of DNA and were expressed as $\mathrm{m} \mu \mathrm{g}$ atoms of DNA-P. Standard DNA solution containing $1000 \mathrm{~m} \mu \mathrm{g}$ atoms phosphorus per $\mathrm{ml}$ was prepared by dissolving 40 mg highly polymerised calf thymus DNA (Serva Chemicals GmbH, Heidelberg, Germany) in $100 \mathrm{ml}$ $5 \mathrm{nM} \mathrm{NaOH}$. DNA values of perfusion specimens were divided by the duration of the perfusion for the respective specimen, to yield the rate of accumulation of DNA in the stomach (m $\mu \mathrm{g}$ atoms DNA-P/min). The lowest rate of accumulation of DNA for each test was used to measure DNA loss from the gastric mucosa as this value has been shown to have a reproducibility of $\pm 10 \%$ (Croft et al., 1966).

\section{MEASUREMENT OF GASTRIC}

GLYCOPROTEIN NANA

In gastric aspirates, free $\mathrm{N}$-acetylneuraminic acid (NANA) was determined by the thiobarbituric acid method developed by Aminoff (1961). As this assay measures only free sialic acids, gastric juice samples

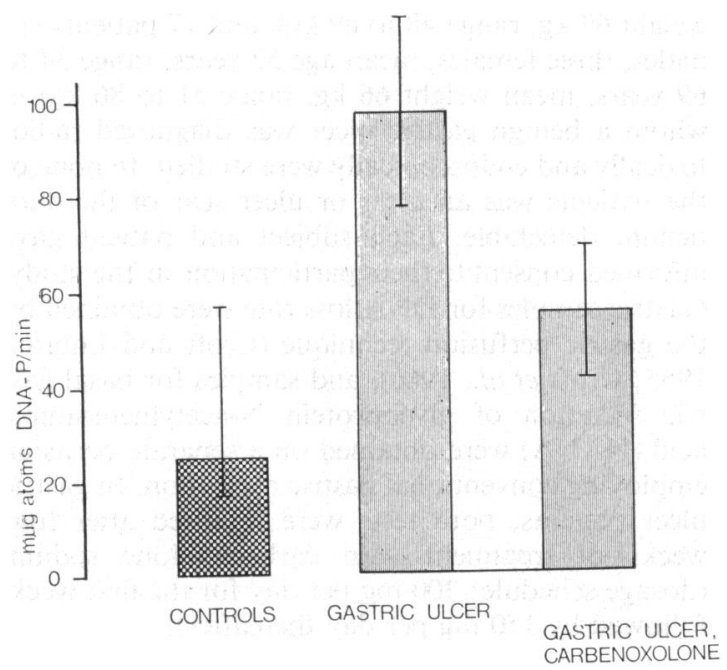

Fig. 1 Rate of gastric DNA (cell) loss in 19 control subjects and 17 gastric ulcer patients before and after four weeks of carbenoxolone sodium therapy.

DNA = deoxyribonucleic acid, $P=$ phosphorus.

Means $\pm S D$ and medians with $95 \%$ confidence

limits, DNA (cell) loss in gastric ulcer patients was significantly $(\mathrm{P}<0.01)$ higher than in normal subjects and fell significantly $(\mathrm{P}<0.01)$ after healing with carbenoxolone. were heated at $80^{\circ}$ for one hour in $0.1 \mathrm{~N} \mathrm{H}_{2} \mathrm{SO}_{4}$ (Warren, 1959a) to release bound sialic acids without degradation (Warren, 1959b). Subsequently, the total NANA content could be estimated quantitatively by the Aminoff procedure. From the difference between total and free NANA the bound fraction, corresponding to glycoprotein NANA, was calculated. Secretory rates were given as $\mu \mathrm{mol}$ bound NANA produced per hour.

\section{STATISTICS}

The results were expressed as means \pm SD in the case of normal distribution of sample values and as medians with $95 \%$ confidence limits in the case of non-normal distribution of sample values (Sachs, 1972). Differences between measurements were analysed statistically by means of Student's $t$ test with normally distributed data and Wilcoxon's signed rank test with non-normally distributed data (Snedecor and Cochran, 1967). The degree of correlation between gastric outputs of glycoprotein NANA and gastric DNA loss rates was obtained using the rank correlation coefficient $\left(r_{s}\right)$ of Spearman (Snedecor and Cochran, 1967).

\section{Results}

GASTRIC DNA LOSS (Figs. 1 and 2)

In the gastric ulcer patients, the rate of accumulation of DNA in gastric washings $(87 \pm 39 \mathrm{~m} \mu \mathrm{g}$ atoms DNA-P/min) significantly exceeded that in controls (median: 24, 95\% confidence limits: $16-56 \mathrm{~m} \mu \mathrm{g}$ atoms DNA-P/min; P < 0.01). After carbenoxolone therapy, the originally enhanced gastric DNA loss rates were significantly less $(55 \pm 27 \mathrm{~m} \mu \mathrm{g}$ atoms DNA-P/min; $P<0.01)$ but were still higher than normal values $(\mathrm{P}<0.05)$.

\section{GASTRIC JUICE GLYCOPROTEIN NANA}

(Fig. 2)

In the healthy subjects $(n=19)$, gastric secretory rates of the glycoprotein bound NANA fraction were $11.5 \pm 6.4 \mu \mathrm{mol} / \mathrm{h}$. In the gastric ulcer patients $(\mathrm{n}=17)$, NANA secretion was $10.5 \pm 5.7 \mu \mathrm{mol} / \mathrm{h}$ before treatment and was significantly increased after four weeks of carbenoxolone therapy (median: 15.0, $95 \%$ confidence limits: $8.7 ; 19.6 \mu \mathrm{mol} / \mathrm{h} ; \mathrm{P}<0.01$ ).

CORRELATION BETWEEN GASTRIC DNA LOSS AND NANA SECRETION

In the healthy controls, there was a significant negative correlation ( $\left.\mathrm{rs}_{\mathrm{S}}=-0.522, \mathrm{P}<0.025\right)$ between DNA and mucus - that is, the greater the gastric DNA loss, the smaller was the NANA output (Fig. 3). In the gastric ulcer patients, the correlation between NANA and DNA outputs did not 


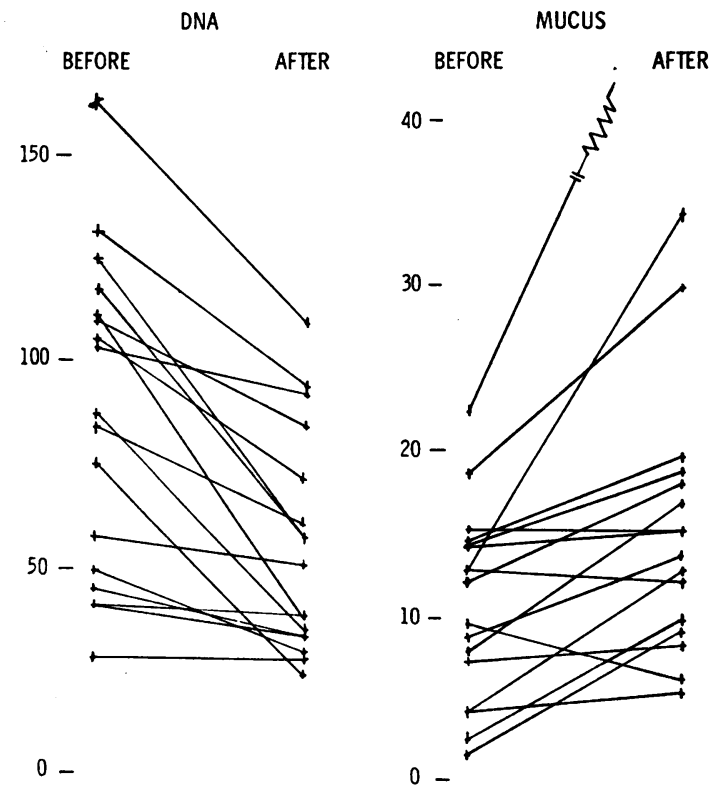

Fig. 2 Paired data from 17 patients with gastric ulcer before and after treament with carbenoxolone. On left gastric DNA (cell) loss in $\mathrm{m} \mu \mathrm{g}$ atoms DNA.P per min and on right NANA (mucus) secretion in $\mu$ mol/hour. The fall in cell turnover and rise in mucus production were both significant $(\mathrm{P}<0.01)$.

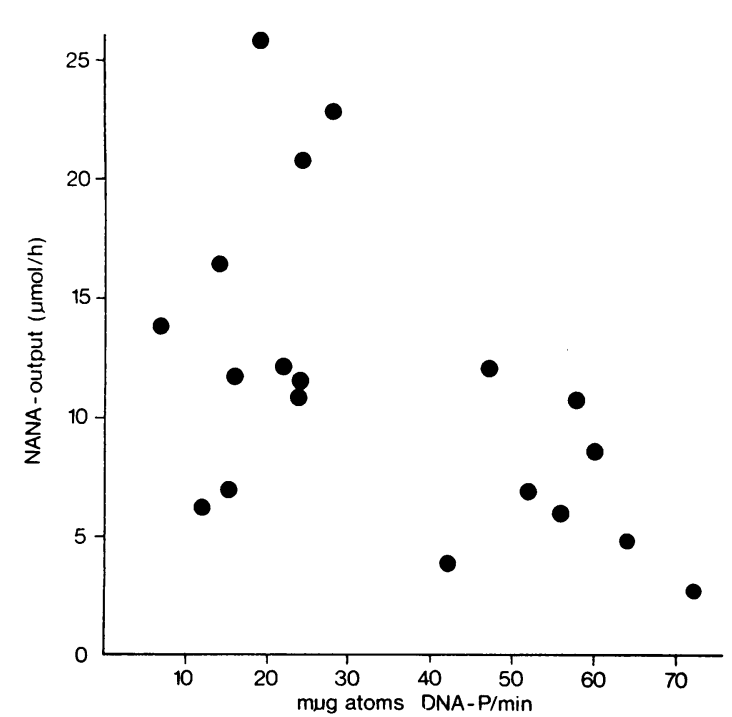

Fig. 3 Intraindividual measurements of rate of gastric DNA (cell) loss and output of glycoprotein NANA (mucus) in 19 healthy subjects. The negative correlation was significant $\left(r_{s}=-0.522, \mathrm{P}<0.025\right)$. reach the level of significance. However, after carbenoxolone therapy, the results showed a correlation that was more like the control findings $\left(\mathrm{r}_{\mathrm{s}}=\right.$ $-0.425, \mathrm{P}<0.1)$.

\section{Discussion}

A gastric ulcer represents the adverse outcome of conflict between aggressive forces in the stomach (hydrochloric acid, pepsin activity, refluxed bile and lysolecithin, ingested noxious agents, etc.), and the defence mechanisms. The mucus layer provided by the epithelial cells of the stomach has been postulated as the 'first line of defence' (Hollander, 1954). As 'second line of defence', the healthy epithelial cells themselves have been thought to play a part. Defective synthesis and secretion of glycoproteins of gastric mucus have been shown both in patients with gastric ulceration (Domschke et al., 1972; Johnston et al., 1975) and in rats and ferrets after administration of ulcerogenic drugs (Johnston et al., 1975). This has been, in principle, confirmed in the present study. On the other hand, the rate of exfoliation of epithelial cells from gastric mucosa has been reported to be increased in gastric ulcer patients (Boyes et al., 1971; Croft, 1973), which is also confirmed by this study. It is probable that this is caused by the high cell turnover which has been measured in atrophic gastritis (Croft et al., 1966; Croft, 1973) a condition of the mucosa which coexists with chronic gastric ulceration.

In experimental animals, as gastric epithelial cells differentiate they mature and produce mucus (Lipkin, 1971). This is in keeping with the present study of healthy human subjects which showed an inverse correlation between gastric mucus secretory rates and epithelial cell turnover, suggesting that the longer the lifespan of the cell the more mucus is produced. In a gastric ulcer the shortened life-cycle of gastric epithelial cells results in a shorter period during which synthesis and secretion of mucus can occur. This interdependence is demonstrated nicely by treatment with carbenoxolone sodium which increases the lifespan of the rapidly proliferating mucosal cells leading to decreased extrusion of gastric epithelial cells (Lipkin, 1970; Boyes et al., 1971; Croft, 1973) and enhanced synthesis and secretion of gastric mucus (Goodier et al., 1967; Gheorghiu et al., 1971; Domschke et al., 1972; Johnston et al., 1975). In the present study both these effects of carbenoxolone therapy were measured simultaneously in patients with gastric ulcer before and after healing. After carbenoxolone an almost normal relationship between gastric mucus production and gastric epithelial cell loss was attained, whereas before therapy high cell turnover had pre- 
vented cell maturation resulting in less mucus production.

\section{References}

Aminoff, D. (1961). Methods for the quantitative estimation of $\mathrm{N}$-acetylneuraminic acid and their application to hydrolysates of sialomucoids. Biochemical Journal, 81, 384-392.

Boyes, B. E., Crean, G. P., and Watkinson, G. (1971). Studies in the rates of epithelial cell exfoliation from gastric mucosa in normal and in ulcer subjects. Gut, 12, 867.

Burton, K. (1956). A study of the conditions and mechanism of the diphenylamine reaction for the colorimetric estimation of deoxyribonucleic acid. Biochemical Journal, 62, 315323.

Croft, D. N. (1973). Gastritis-cell turnover studies. In Topics in Gastroenterologv, pp. 58-64. Edited by S. C. Truelove and D. P. Jewell. Blackwell: Oxford.

Croft, D. N., and Lubran, M. (1965). The estimation of deoxyribonucleic acid in the presence of sialic acid; application to analysis of human gastric washings. Biochemical Journal, 95, 612-620.

Croft, D. N., Pollock, D. J., and Coghill, N. F. (1966). Cell loss from human gastric mucosa measured by the estimation of deoxyribonucleic acid in gastric washings. Gut, 7, 333-343.

Domschke, W., Domschke, S., Classen, M., and Demling, L. (1972). Some properties of mucus in patients with gastric ulcer. Effect of treatment with carbenoxolone sodium. Scandinavian Journal of Gastroenterology, 7, 647-651.
Gheorghiu, Th., Frotz, H., and Klein, H. J. (1971). Experimentelle und klinische Untersuchungen zum Mechanismus der Carbenoxolonwirkung. I. Einfluss von Carbenoxolon auf die Magensaft-Mucus-Sekretion der Ratte. Verhandlungen der Deutschen Gesellschaft für Innere Medizin, 77, 511-515.

Goodier, T. E. W., Horwich, L., and Galloway, R. W. (1967). Morphological observations on gastric ulcers treated with carbenoxolone sodium. Gut, 8, 544-547.

Hollander, F. (1954). The two-component mucous barrier. Archives of Internal Medicine, 93, 107-120.

Lipkin, M. (1970). Carbenoxolone sodium and the rate of extrusion of gastric epithelial cells. Chapter in Carbenoxolone Sodium, pp. 11-15. Edited by J. H. Baron and F. M. Sullivan. Butterworths: London.

Lipkin, M. (1971). In 'defence' of the gastric mucosa. Gut, 12, 599-603.

Johnston, B., Lindup, W. E., Shillingford, J. S., Smith, M., and Parke, D. V. (1975). The pharmacological-biochemistry of carbenoxolone. Its effects on gastric mucus. In Fourth Symposium on Carbenoxolone, pp. 3-21. Edited by Sir F. Avery-Jones and D. V. Parke. Butterworths: London.

Sachs, L. (1972). Angewandte Statistik. 3rd edn. Springer: Berlin,

Snedecor, G. W., and Cochran, W. G. (1967). Statistical Methods, 6th edn. Iowa State University Press: Ames.

Warren. L. (1959a). The thiobarbituric acid assay of sialic acids. Journal of Biological Chemistry, 234, 1971-1975.

Warren, L. (1959b). Sialic acid in human semen and in the male genital tract. Journal of Clinical Investigation, 38, 755761. 